Sains Malaysiana 50(7)(2021): 1987-1996

http://doi.org/10.17576/jsm-2021-5007-13

\title{
The Combination of bFGF and Hydrocortisone is a Better Alternative Compared to 5-Azacytidine for Cardiomyogenic Differentiation of Bone Marrow and Adipose Stem Cells
}

(Gabungan bFGF dan Hidrokortison adalah Alternatif yang Lebih Baik Berbanding dengan 5-Azasitidin bagi Perbezaan Kardomiogen Sumsum Tulang dan Sel Stem Adipos)

\author{
Nadiah Sulaiman*, Nur Qisya Afifah Veronica Sainik, Shamsul bin Sulaiman, Pezhman Hafez, Ng Min \\ HWEI \& RUSZYMAH BT HJ IDRUS
}

\section{ABSTRACT}

Stem cells can be differentiated into cardiomyocytes by induction with 5-azacytidine (5-aza) but its carcinogenicity is of concern for future translational application. Alternatively, growth factors and hormones such as basic fibroblast growth factor (bFGF) and hydrocortisone have been reported to act as a therapeutic inducer for cardiomyocytes differentiation. In this study, we aim to investigate the ability of bFGF and hydrocortisone in combination to stimulate the differentiation of mesenchymal stem cells (MSC) into cardiomyocytes lineage. Sheep adipose tissue stem cell (ATSC) and bone marrow stem cell (BMSC) were isolated, cultured and induced with the three groups of induction factors; 5-aza alone, the combination of hydrocortisone and bFGF and all three factors in combination for cardiomyogenic differentiation. Morphological, protein and functional ability of both ATSC and BMSC were observed and analysed to confirm cardiomyocyte differentiation. Viability of BMSC and ATSC in each treated group was significantly higher $(P<0.05)$ on both cells after treated with $10 \mathrm{nM}$ of bFGF and $50 \mu \mathrm{M}$ of hydrocortisone. Cardiomyocyte proteins; $\alpha$-Sarcomeric actin ( $\alpha S A)$ and Phospolamban (Plb) was detected in both ATSC and BMSC exposed to induction factors but not in the control negative group. Both ATSC and BMSC without induction factors showed only minute cell number possesses $\alpha \mathrm{SA}$ and Plb. Calcium ion $\left(\mathrm{Ca}^{2+}\right)$ spark was observed in primary heart cells. Similarly, $\mathrm{Ca}^{2+}$ spark was also detected in induced ATSC and BMSC, proving some functionality of induced cells. In conclusion, bFGF and hydrocortisone are safer induction factor compared to the currently used 5-aza as both showed higher viability after induction, therefore more cells are available for future use in cardiac tissue engineering.

Keywords: 5-Azacytidine; basic Fibroblast Growth Factor; cardiomyocytes differentiation; hydrocortisone; stem cells

ABSTRAK

Sel induk boleh dibezakan menjadi kardiomiosit dengan aruhan 5-azasitidin (5-aza) tetapi sifat karsinogeniknya menimbulkan kerisauan bagi kegunaan klinikal pada masa hadapan. Sebagai alternatif, faktor pertumbuhan dan pelbagai jenis hormon seperti faktor pertumbuhan fibroblas asas (bFGF) dan hidrokortison dilaporkan boleh bertindak sebagai pemacu terapi untuk pembezaan kardiomiosit. Kajian ini bertujuan untuk mengkaji kemampuan bFGF dan hidrokortison secara gabungan untuk merangsang pembezaan MSC kepada leluhur kardiomiosit. Sel dasar lemak (ATSC) dan tulang sum-sum kambing (BMSC) diasingkan, dikultur dan diaruh dengan tiga kumpulan faktor aruhan; 5-aza sahaja, gabungan hidrokortison dan bFGF dan ketiga-tiga faktor gabungan untuk pembezaan kardiomogenik. Perubahan morfologi, protein dan fungsi kedua-dua ATSC dan BMSC dikaji dan dianalisis untuk mengesahkan pembezaan leluhur kardiomiosit. Perkembangan ATSC dan BMSC pada setiap kumpulan yang dirawat jauh lebih tinggi $(P<0.05)$ pada kedua-dua sel setelah dirawat dengan $10 \mathrm{nM} \mathrm{bFGF} \mathrm{dan} 50 \mu \mathrm{M}$ hidrokortison. Protein kardiomiosit, $\alpha$-Sarcomeric actin ( $\alpha S A$ ) dan Phospolamban (Plb) dikesan pada kedua-dua ATSC dan BMSC yang terdedah kepada faktor aruhan tetapi tidak dalam kawalan negatif. Kedua-dua sel, ATSC dan BMSC tanpa faktor aruhan menunjukkan hanya sebilangan kecil sel mempunyai $\alpha$ SA dan Plb. Percikan ion kalsium $\left(\mathrm{Ca}^{2+}\right)$ diperhatikan pada sel jantung primer, yang turut dikesan pada ATSC dan BMSC yang diinduksi. Maka, sel yang diinduksi sedikit sebanyak berfungsi seperti kardiomiosit. Kesimpulannya, bFGF dan hidrokortison adalah faktor aruhan yang lebih selamat berbanding dengan 5-Aza yang digunakan sekarang. Hal ini demikian adalah kerana kedua-duanya menunjukkan perkembangan yang lebih tinggi selepas aruhan, oleh itu lebih banyak sel tersedia untuk kegunaan pada peringkat klinikal.

Kata kunci: 5-azasitidin; faktor tumbesaran fibroblas asas; hidrokortison; pembezaan kardiomiosit; sel dasar 


\section{INTRODUCTION}

World Health Organization (WHO) reported that almost $30 \%$ or 17.3 million of all global deaths were caused by cardiovascular diseases (Kaptoge et al. 2019). There are a variety of treatment practices in dealing with heart diseases. Unfortunately, current applied treatment regime such as pharmacological treatment and interventional approaches were focusing on slowing the progression of the disease rather than curing the disease entirely (Leon 2015; Ludman 2018; Ogawa et al. 2019).

The heart initially coined as a terminally differentiated organ due to its limited to none self-renewal ability (Steinhauser \& Lee 2011). The perception has now changed when a population of cardiac stem cells were discovered (Zhang et al. 2015). When myocardial infarction or heart attack occurs, this would lead to death of cardiomyocytes. To compensate the loss of cardiomyocytes, the heart will undergo hypertrophy where the surviving cells size increase with no or limited increase in cell numbers (Peter et al. 2016). Hypertrophy however, could not heal the heart as the increase in cell size does not increase the pumping ability of the heart.

Hence, alternative source of cardiomyocytes are in need to replace the cardiomyocytes loss after infarction. Injected stem cells were shown to localize the diseased area of the heart and in part manage to restore the heart function (Segers \& Lee 2008). Unfortunately, reports on the effectiveness of injected stem cells for myocardial infarction treatments are non-definitive and more clinical trials are still on-going (Clifford et al. 2012). Additionally, calcification that occurred with the use of unselected bone marrow stem cells and loss of delivered stem cell at early phase contribute to the non-favourable outcome of injected stem cells (Yoon et al. 2004). Presumably, more positive outcome is expected from the use of stem cells which was induced to cardiomyocytes in vitro before in vivo application.

Various studies described the capability of mesenchymal stem cells to differentiate into various types of cells, including cardiomyocytes. Mesenchymal stem cells could be obtained from various tissues e.g. bone marrow, adipose tissue and dermal tissue, thus offers numerous sources of donor cell for heart regeneration (Steinhauser \& Lee 2011). A DNA methyltransferase inhibitor, 5-azacytidine (5-aza), has been widely for cardiomyogenic differentiation (Stern-Straeter et al. 2014). 5 -azacytidine is commonly used as an anti-cancer drug where the mechanism of action focusses on the arrest of cell cycle and cause apoptosis ( $\mathrm{Li}$ et al. 2016). As deoxy derivatives that could potentially cause mutation, safety issues of 5-aza as a cardiomyogenic differentiation agent in future translational application are of concern (Kelecsényi et al. 2000). A collection of alternative methods had been applied to induce mesenchymal stem cells (MSCs) into cardiomyocytes lineage, including the use of growth factors (Kawai et al. 2004), co-culture with primary cardiomyocytes (Choi et al. 2010) and more interestingly the use of herbs like Dan-shen root (Li et al. 2011).

In finding an alternative to 5-aza, the use of factors that influence the cardiomyogenic differentiation of MSCs during embryogenesis was explored. Factors such as fibroblast growth factor (FGF), bone morphogenetic proteins (BMPs) and the Wnt proteins are known to play significant role in cardiogenesis (Brade et al. 2013). Basic fibroblast growth factor (bFGF) is a potent proliferative agent for MSCs and was proven to direct MSCs migration (Colenci et al. 2014). The benefit of using corticosteroid in the treatment of myocardial infarction and its cardioprotective effect are of interest (Giugliano et al. 2003). Hydrocortisone is an agent of stress hormone produced by the adrenal gland and was reported to stimulate the multipotency of MSCs and enhances proliferation of cardiomyocytes in vitro (Shipunova et al. 2013). Therefore, we were looking into the synergetic effect of both bFGF and hydrocortisone in differentiating MSCs into cardiomyocytes.

\section{MATERIALS AND METHODS}

\section{CELLS ISOLATION AND CULTURE}

The use of animals was according to the approval by the Animal Care and Use Committee (UKMAEC) PP/ FISIO/2009/RUSZYMAH/29-APRIL/260-MAY-2009DECEMBER-2010 at Universiti Kebangsaan Malaysia. Bone marrows were collected from sheep iliac crest and subjected to Ficoll-Hypaque (Amersham Biosciences, Uppsala, Sweden) density gradient centrifugation to harvest the peripheral blood mononuclear cells as described (Zhao et al. 2012). Cell pellets collected were cultured in 6-well plate and incubated in 5\% $\mathrm{CO}_{2}$ incubator at $37{ }^{\circ} \mathrm{C}$. Sheep adipose tissues were collected and digested with $0.075 \%$ Collagenase Type I (Worthington Biochemical Corp., Freehold, NJ). Cell Strainer (100 $\mu \mathrm{m})$ (Fisher Scientific, Pittsburgh, USA) was used to separate debris after digestion. Liquidized samples were then centrifuged at $6000 \mathrm{rpm}$ for $5 \mathrm{~min}$ at $37^{\circ} \mathrm{C}$ to collect the cell pellets and resuspended with buffer solution. The cells were plated in 6-well plate and incubated in 5\% $\mathrm{CO}_{2}$ incubator at $37^{\circ} \mathrm{C}$. Heart was collected from sheep and $1 \mathrm{~cm}^{3}$ block of the left ventricle heart tissue was cut out. Samples were minced and subjected to digestion with $0.075 \%$ Collagenase Type I and centrifuged at $6000 \mathrm{rpm}$ for $5 \mathrm{~min}$ at $37^{\circ} \mathrm{C}$. Pellets were resuspended with culture medium (Iscove's Modified Dulbecco's Medium (IMDM) (Gibco/BRL, Bethesda, MD) supplemented with 10\% fetal bovine serum (FBS) (Invitrogen, Carlsbad, CA), 2\% HEPES (Invitrogen, Carlsbad, CA), 1\% antibioticantimitotic (Invitrogen, Carlsbad, CA), 1\% GlutaMAX ${ }^{\mathrm{TM}_{-} \mathrm{I}}$ 
(Gibco/BRL, Bethesda, MD) and 1\% L-Ascorbic acid (SigmaAdrich, Ontario, CA). The cells were plated in 6-well plate and incubated in $5 \% \mathrm{CO}_{2}$ incubator at $37{ }^{\circ} \mathrm{C}$.

\section{EXPERIMENTAL DESIGN}

The cells were subjected to induction factors exposure for only $24 \mathrm{~h}$. Cells were assigned to four groups, as follows: Group 1: Control or Untreated group; Group 2: Treated group with $5 \mu \mathrm{M}$ of 5-azacytidine; Group 3: Treated group with $10 \mathrm{nM}$ of bFGF and $50 \mu \mathrm{M}$ of hydrocortisone; Group 4: Treated group with $5 \mu \mathrm{M}$ of 5-azacytidine, 10 $\mathrm{nM}$ of bFGF and $50 \mu \mathrm{M}$ of hydrocortisone.

All induction factors were purchased from SigmaAldrich. All culture plate medium was changed to culture medium without induction factors after $24 \mathrm{~h}$. Cells from each group were observed for morphological changes and cultured to confluency for further analysis.

\section{CELL VIABILITY ASSAY}

Viability of both experimented tissue samples (ATSC and BMSC) at every passage (P1- P3) was measured via Trypan blue exclusion method using a haemocytometer.

\section{IMMUNOCYTOCHEMICAL STAINING}

BMSC and ATSC at 70-80\% confluency in 8-well chamber slide were used. Both cells were rinse with PBS twice and fixed with $4 \%$ paraformaldehyde (SigmaAdrich, Ontario, CA) for $10 \mathrm{~min}$. The cells were incubated with the primary antibody monoclonal $\alpha$-sarcomeric actin antibody (Abcam cat\#ab7799) and monoclonal phospholamban antibody (Abcam cat\#ab2865)) at $4{ }^{\circ} \mathrm{C}$ for overnight. Next, the secondary antibody (rabbit IgG anti-mouse conjugated with fluorescein isothiocyanate (FITC) (Millipore cat\#AP160)) was added and incubated for 1 $\mathrm{h}$ at room temperature. After washing, 4>,6-diamidino-2phenylindole (DAPI) (Invitrogen, Carlsbad, CA) was added and incubated for $30 \mathrm{~min}$. The slide was observed under a confocal microscope.

\section{CALCIUM IMAGING}

Cells were cultured in Wilco dishes (Willco Wells B.V., Amsterdam, NL) and once appropriate density was achieved, medium was discarded. Cells were washed with PBS three times before Bovine Serum Albumin (BSA) (SigmaAdrich, Ontario, CA) was added to assist with dye mixing. A total $5 \mu \mathrm{M}$ of FluoroPure grade fluo-3 AM (Invitrogen, Carlsbad, CA) was loaded into the culture dish and incubated for $30 \mathrm{~min}$ at $37^{\circ} \mathrm{C}$ in the dark. The cells were washed with PBS three times. The dish was filled with calcium-free/phenol red-free medium (Gibco/BRL, Bethesda, MD) and $1.25 \mathrm{mM} \mathrm{CaCl}$ (Fluka Chemical Corp., Milwaukee, USA) followed by image recording using confocal microscope. Calcium sparks were then analysed through Spark Master Plugin in the ImageJ software (https://imagej.nih.gov/ij/) using captured images.

\section{STATISTICAL ANALYSIS}

Data are presented as mean \pm Standard Error of Mean (SEM). Statistical analyses were performed with SPSS v15.0 software. Statistical significance was evaluated using one-way ANOVA and a Post Hoc t-Test among each group. The differences with values less than 0.05 $(P$-value $<0.05)$ were considered statistically significant.

\section{RESULTS}

\section{MORPHOLOGICAL OBSERVATION}

The ATSC and BMSC cultures comprised of fibroblastlike spindle-shape cells and large triangular- or star-shape cells (Figure 1). The cells were grown to confluency at primary passage $(\mathrm{P} 0)$. After $24 \mathrm{~h}$ of seeding at (P1), followed with induction treatment for $24 \mathrm{~h}$, there were no apparent morphological changes observed in all treated groups of ATSC. Cells from subsequent passaging (P2 and P3) do not exhibit any evident of morphological differences as previous passage. BMSC on the other hand consists mostly of fibroblast-like spindle-shape cells (postinduction) (Figure 1). To obtain a more homogenous cell population, exposure to induction medium were done at P1, $24 \mathrm{~h}$ after seeding for $24 \mathrm{~h}$. There were no noticeable morphological changes after the treatment throughout P1 and subsequent P2 and P3 cultures. Left ventricular heart tissues were known to harbor more cardiomyocytes. After tissue digestion, cells collected from left ventricular heart tissue were plated and cultured to confluency at P0 to be use as positive control. The plated cells viewed were morphologically polygonal with various sizes (Figure 1).

\section{CELLS VIABILITY}

Viability of both experimented tissue samples (ATSC and BMSC) at P1 until P3 were monitored as it shows the cells potential to be manipulated in vitro. Viability was accessed by Trypan blue exclusion test of cell viability. Independent t-test was done to compare the viability of ATSC and BMSC in all treated groups versus passage performed (Figure 2). At passage 1, the viability of BMSC (Figure 2(a)) and ATSC (Figure 2(b)) in each treated group showed significantly higher viability $(\mathrm{P}<0.05)$ with $10 \mathrm{nM}$ of bFGF and $50 \mu \mathrm{M}$ of hydrocortisone as compared to cells treated with only $5 \mu \mathrm{M}$ of 5 -azacytidine.

\section{EXPRESSION OF CARDIAC PROTEINS}

The positive-stained cells with antibody $\alpha$-Sacromeric actin $(\alpha \mathrm{SA})$ and phospholamban (Plb) were seen as green 
with blue nucleus (FITC conjugated secondary antibody gave green florescence with nuclei staining using DAPI gave blue florescence). All treated groups of both ATSC and BMSC showed positive expression of $\alpha \mathrm{SA}$ and Plb (Figure 3(a)). Quantitative analysis shows higher PLB and $\alpha \mathrm{SA}$ expression were observed in all induced BMSC than control BMSC. Whereas both proteins expression in induced ATSC does not differ significantly from the control ATSC (Figure 3(b)).

\section{CALCIUM SPARKS DETECTED}

Control and treated ATSC and BMSC were further analysed through the use of fluorescent dye for measurement of intracellular free calcium concentration $\left(\left[\mathrm{Ca}^{2+}\right]_{\mathrm{i}}\right)$. The ability of cells to uptake extracellular calcium ion was monitored to identify its similarity with native cardiomyocytes where calcium ions are crucial in the cells beating (Figure 4). The calcium sparks were recorded through Spark Master Plugin in the ImageJ Program. Calcium spark is a brief, localized increase of myoplasmic $\mathrm{Ca}^{2+}$ detected through $\mathrm{Ca}^{2+}$ indicator such as fluo-3 that bound to $\mathrm{Ca}^{2+}$ and fluoresce. Observation on calcium spark of ATSC and BMSC induced with bFGF and hydrocortisone showed the presence of calcium spark at several locations in some induced cells as in Figure 4. Boxed areas showed the location of calcium sparks detected on cells that correlate to the surface plot shown. Extracellular level of calcium ion is low in cardiomyocytes in comparison with ATSC and BMSC even though the same amount of $1.26 \mathrm{mM}$ of $\mathrm{CaCl}_{2}$ was introduced in culture right before imaging were done.

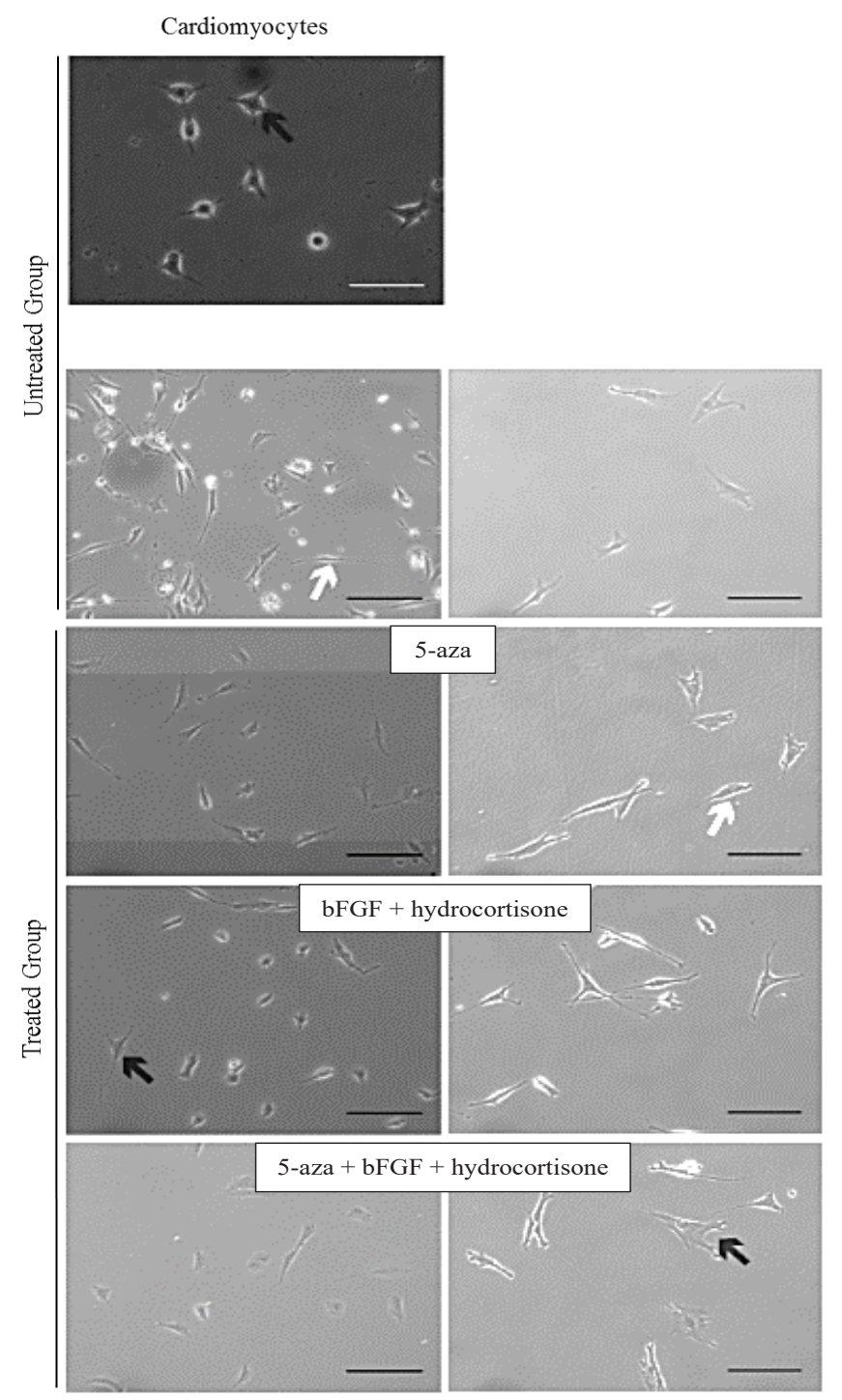

FIGURE 1. Morphology comparison of primary cells at day 3 in culture of the cells at P1. ATSC and BMSC exhibit similar number and morphology of fibroblastic shaped cells (white arrow) $24 \mathrm{~h}$ after treatment at day 3 in culture of the cells at P1. Cardiomyocytes act as a positive control was imaged at day 3 of the cells at P1 observed to have triangular or star-shaped cells (black arrow) [Scale Bar $=250 \mu \mathrm{m}$ ] 
a)
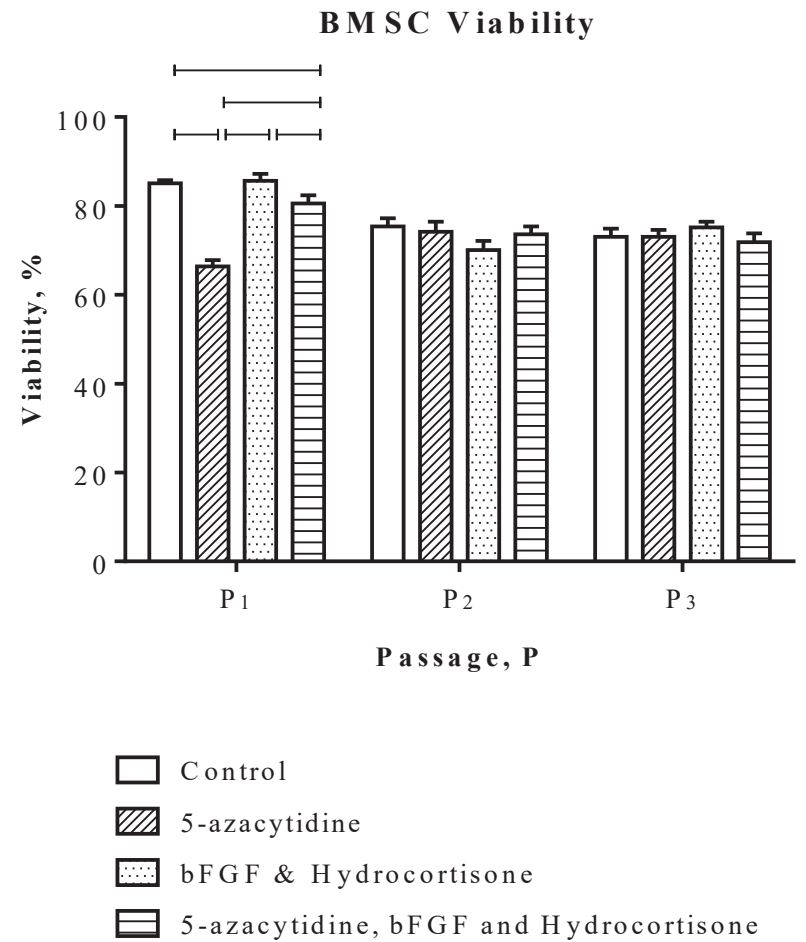

b)

A T SC Viability

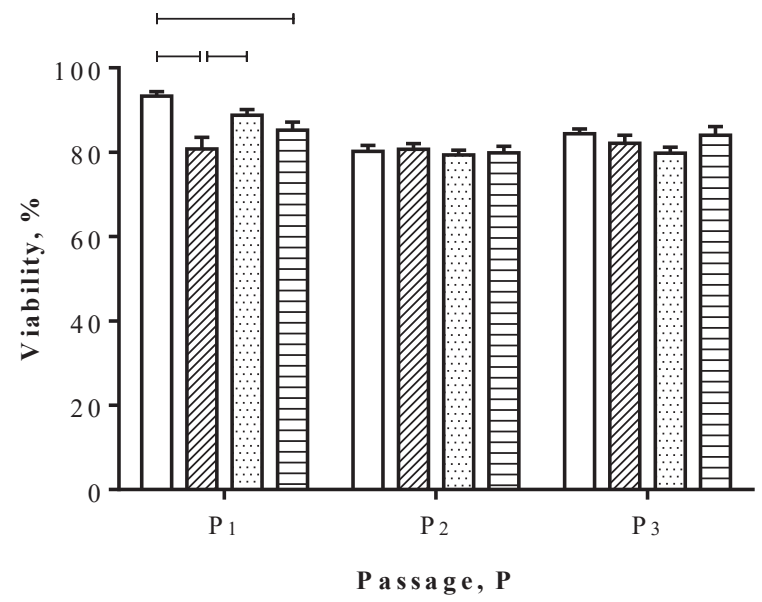

FIGURE 2. Histogram showed viability of BMSC (A) and ATSC (B) in each treated group at passage 1,2 and 3, respectively. 5-Aza significantly inhibits ATSC and BMSC viability but the cells viability was not altered in following passages. ATSC and BMSC viability was affected with the use of induction factors in culture at $\mathrm{P} 1$ with $<0.05$ (One-way ANOVA) 
a) ATSC

$\underline{a S A}$

$\underline{\mathrm{Plb}}$

BMSC

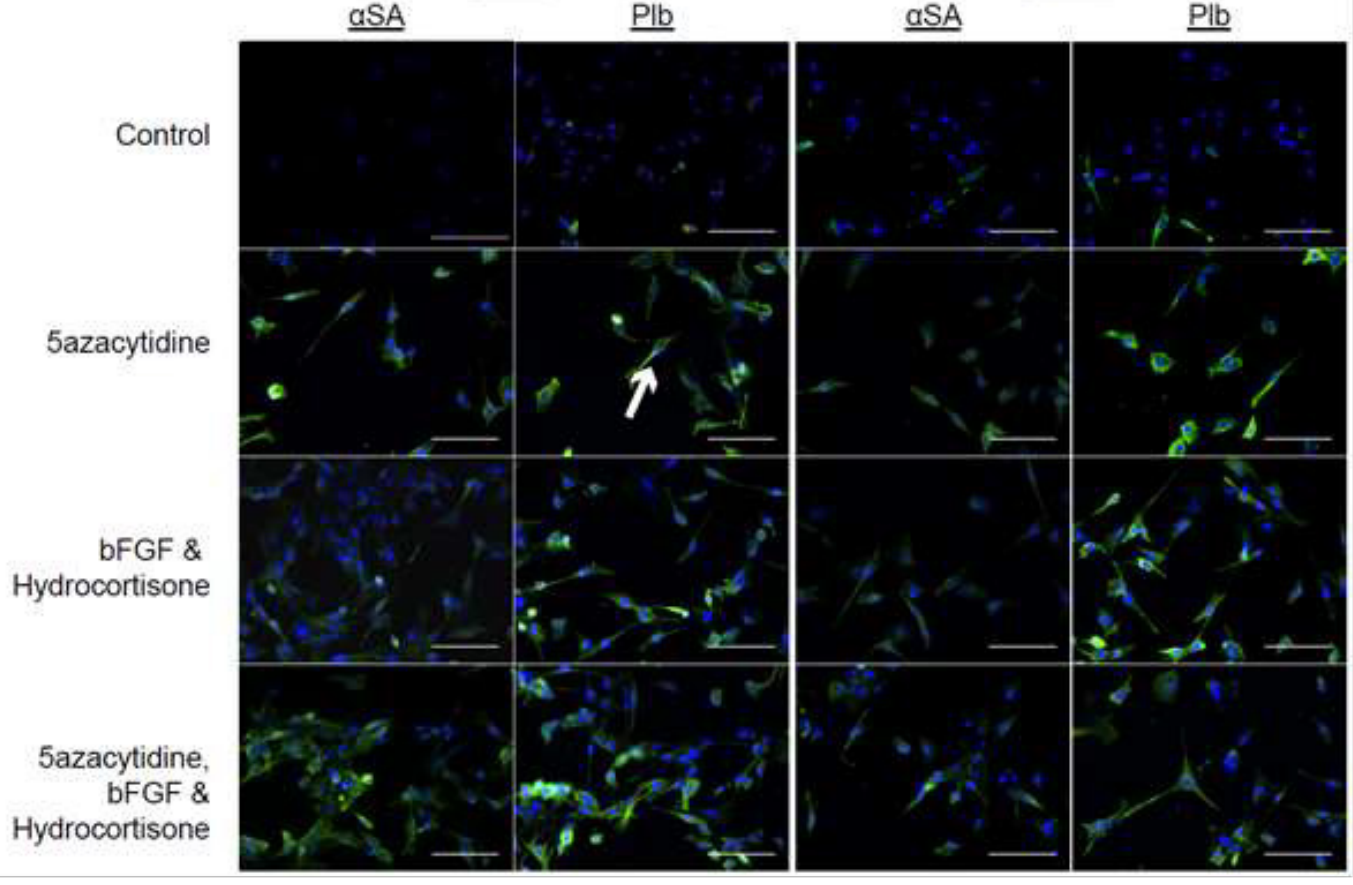

b) Induced ATSC and BMSC PLB Expression

Induced ATSC and BMSC $\alpha$ SA Expression

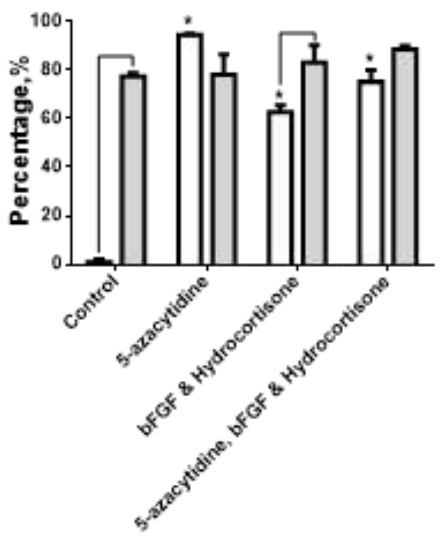

Treatment Groups
口 $\mathrm{BMSC}$ PID
口ADSC PID

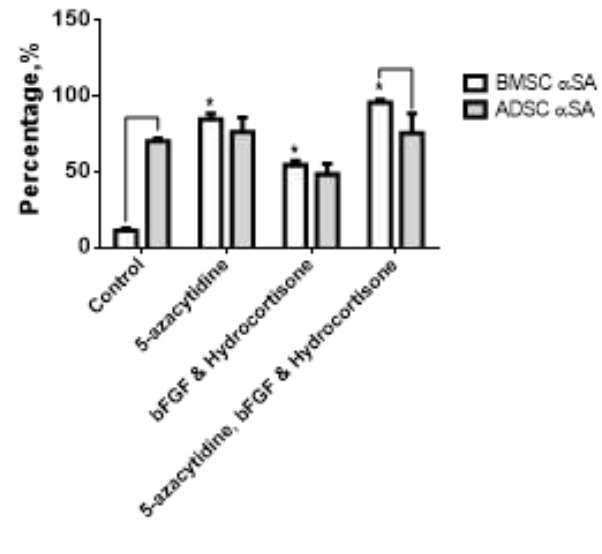

Treatment Groups

FIGURE 3. Immunocytochemical analysis. Comparison expression of $\alpha$-Sarcomeric actin $(\alpha \mathrm{SA})$ and phospholamban $(\mathrm{Plb})$ in treated group of ATSC and BMSC.

Immunocytochemical analysis at $\mathrm{P} 1$ shows minute number of cells with positive staining in the control group. Positive stained cells numbers increase significantly with the use of induction factors in BMSC but not in ATSC culture (One-way ANOVA). Positive stained cells appear green with blue nucleus (white arrow) [Scale Bar $=250 \mu \mathrm{m}]$ 
Cardiomyocytes
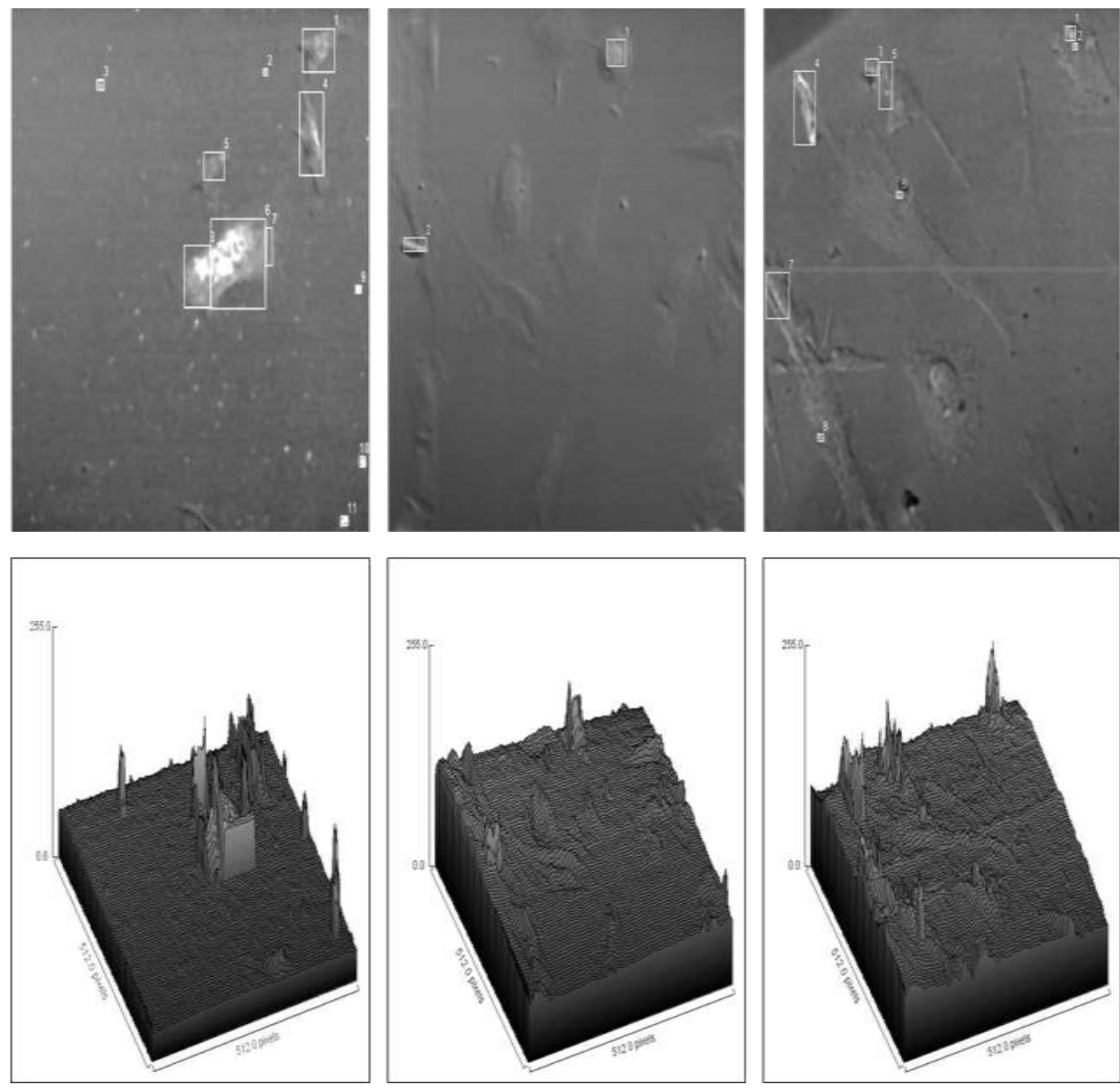

FIGURE 4. Calcium sparks analyses on cardiomyocytes; ATSC and BMSC (Both treated with $10 \mathrm{nM}$ of $\mathrm{bFGF}$ and $50 \mu \mathrm{M}$ of hydrocortisone) were showed in surface plot (Boxed area) where the sparks correlate with the increase of calcium ion at the same location in the cells

\section{DISCUSSION}

Death of cardiomyocytes due to myocardial infarction and the limited to none proliferative ability of cardiomyocyte leads to the search for alternative cardiomyocytes. Alternative cell sources mainly are of stem cells derivatives (Pittenger \& Martin 2004). Vast research has proven the multipotency of stem cells regardless of where they are isolated from Kuhn and Tuan (2010). In this study, we look into the potential of mesenchymal stem cells derived from both bone marrow and adipose tissue. Both sources have been proven of their stemness by other researchers and we work in inducing both types of cells into functional cardiomyocyte-like cells. ATSCs were observed to include small fraction of a broad and larger cells aside from the 
spindle shape cells observed in BMSC. Our morphological observations are in line with other researchers where both BMSC and ATSC at primary culture initially are different but become more homologous after cultured longer (Guo et al. 2018). These features are typical of MSCs in culture. Cardiomyocytes isolated from left ventricular heart exhibit more polygamous shape with large aggregates and intracellular vacuole as reported by previous studies (Bird et al. 2003).

Induction factors are externally introduced to direct growth and maturation of cells to specific lineages. The most used cardiomyogenic induction factor, 5-aza was used alongside bFGF and hydrocortisone to assess their synergistic ability in cardiomyogenic differentiation. Both ATSCs and BMSCs that were exposed to these different induction factors showed no apparent morphological changes in all treatment groups. Since there are no obvious alterations to the cells morphology after exposure to induction factors, the influence of induction factors used on cell viability is of value. Both ATSC and BMSC viability that were exposed to 5-azacytidine for $24 \mathrm{~h}$ was significantly lower than the control group viability. Our results showed that the viability of both ATSC and BMSC were affected with incorporation of 5-azacytidine in the culture medium. However, both cells viability was restored after the passage 1 . Hence, exposure to 5 -aza as early as passage 1 might disrupt the cell establishment in vitro. ATSC and BMSC that were exposed to bFGF and hydrocortisone showed higher viability than those solely exposed to 5-azacytidine. This may be due to the paracrine effect of both factors in addition to the negative effect of 5-azacytidine. bFGF is among the growth factors that contributed to the paracrine effect and helps in cardiomyocytes proliferation and thus regeneration of the heart (Marques et al. 2008).

Distinct characteristic of cardiomyocyte are its ability to contract and beats in vitro. Immunocytochemical staining of essential structural cardiomyogenic proteins; $\alpha$-Sarcomeric actin ( $\alpha$ SA) was detected in both ATSC and BMSC exposed to induction factors but not in the control negative group. The presence of $\alpha \mathrm{SA}$ is important for the contractile activity of cardiomyocytes (Yin et al. 2015). Incorporation of induction factors does contribute to $\alpha \mathrm{SA}$ expression as reported by previous study (Choi et al. 2010; Li et al. 2011). ATSC and BMSC without induction factors showed only minute cell number that possesses $\alpha \mathrm{SA}$. Integral to cardiomyocyte beatings are proteins that regulates calcium ion $(\mathrm{Ca} 2+)$ intake. Phospholamban (Plb) are located at the sarcoplasmic reticulum membrane regulates the level of intracellular $\mathrm{Ca} 2+$ in cardiomyocyte (MacLennan \& Kranias 2003). Unlike other muscle cells, cardiomyocytes utilized $\mathrm{Ca} 2+$ from both intracellular storage and extracellular fluid to generate the mechanism for contraction and relaxation (Loughrey et al. 2002). Plb was detected through immunocytochemical staining in both ATSC and BMSC with exposure to induction factors.

Changes in cytoplasmic free calcium ion concentration $(\Delta[\mathrm{Ca} 2+])$ gave insight on the mechanism of cardiac excitation-contraction coupling. The regulation of cardiac contractility and relaxation involved the phosphorylation of numerous proteins including sarcolemmal calcium channel, phospholamban, troponin I and troponin $\mathrm{C}$ (Olesen et al. 2007). Phosphorylation of calcium channel and Plb increases calcium influx during cardiac activation cycle. Hence causes sarcoplasmic calcium to increase calcium uptake. These events ultimately lead to the contraction and relaxation of cardiomyocytes (Akin et al. 2013). Therefore, to further verify whether both ATSC and BMSC were successfully induced into cardiomyocytes, the detection of $\mathrm{Ca} 2+$ influx is crucial. The cellular process regulated by $\mathrm{Ca} 2+$ concentration usually depends on the spatially localized events at specific activation sites in the cells. The smallest readily detected local $\mathrm{Ca} 2+$ event is termed ' $\mathrm{Ca} 2+$ spark'. $\mathrm{Ca} 2+$ spark is defined as a brief, localized increase of myoplasmic $\mathrm{Ca} 2+$ detected through $\mathrm{Ca} 2+$ indicator such as fluo-3 that bound to $\mathrm{Ca} 2+$ and fluoresce (Knot et al. 2005). In the current study, Ca2+ spark was seen in primary heart cells. Similarly, $\mathrm{Ca} 2+$ spark was also detected in induced ATSC and BMSC, proving the functionality of induced cells. Although $\mathrm{Ca} 2+$ sparks were not detected in every single cell, the presence of the sparks in several cells shows the possibility of induced cells to conform to cardiomyocytes function. Extracellular $\mathrm{Ca} 2+$ concentration or the culture calcium ion concentration was observed to be higher in both ATSC and BMSC as compared to the primary heart cell surface plot. Thus, support cardiomyocyte ability to uptake calcium ion from its surrounding which is a unique ability for cardiomyocyte (Knot et al. 2005).

\section{CONCLUSION}

This study reiterates the ability of MSCs derived from both bone marrow and adipose tissues to differentiate into cardiomyocytes lineage. The synergistic effect of bFGF and hydrocortisone which is less toxic compared to 5-aza is a more preferred choice of cardiomyogenic differentiation.

ACKNOWLEDGEMENTS

This work was funded by the UKMMC Fundamental grant (FF-271-2009). 


\section{REFERENCES}

Akin, B.L., Hurley, T.D., Chen, Z. \& Jones, L.R. 2013. The structural basis for phospholamban inhibition of the calcium pump in sarcoplasmic reticulum. Journal of Biological Chemistry 288(42): 30181-30191.

Bird, S.D., Doevendans, P. A., van Rooijen, M.A., de la Riviere, A.B., Hassink, R.J., Passier, R. \& Mummery, C.L. 2003. The human adult cardiomyocyte phenotype. Cardiovascular Research 58(2): 423-434.

Brade, T., Pane, L.S., Moretti, A., Chien, K.R. \& Laugwitz, K.L. 2013. Embryonic heart progenitors and cardiogenesis. Cold Spring Harbor Perspectives in Medicine 3(10): a013847.

Choi, Y.S., Dusting, G.J., Stubbs, S., Arunothayaraj, S., Han, X.L., Collas, P., Morrison, W.A. \& Dilley, R.J. 2010. Differentiation of human adipose-derived stem cells into beating cardiomyocytes. Journal of Cellular and Molecular Medicine 14(4): 878-889.

Clifford, D.M., Fisher, S.A., Brunskill, S.J., Doree, C., Mathur, A., Watt, S. \& Martin-Rendon, E. 2012. Stem cell treatment for acute myocardial infarction. Cochrane Database of Systematic Reviews (2): CD006536.

Colenci, R., da Silva Assunção, L.R., Bomfim, S.R.M., de Assis Golim, M., Deffune, E. \& Oliveira, S.H.P. 2014 Bone marrow mesenchymal stem cells stimulated by bFGF up-regulated protein expression in comparison with periodontal fibroblasts in vitro. Archives of Oral Biology 59(3): 268-276

Giugliano, G.R., Giugliano, R.P., Michael Gibson, C. \& Kuntz, R.E. 2003. Meta-analysis of corticosteroid treatment in acute myocardial infarction. American Journal of Cardiology 91(9): 1055-1059.

Guo, X., Bai, Y., Zhang, L., Zhang, B., Zagidullin, N., Carvalho, K., Du, Z. \& Cai, B. 2018. Cardiomyocyte differentiation of mesenchymal stem cells from bone marrow: New regulators and its implications. Stem Cell Research and Therapy 9(1): 44.

Kaptoge, S., Pennells, L., De Bacquer, D., Cooney, M.T., Kavousi, M., Stevens, G., Riley, L.M., Savin, S., Khan, T., Altay, S., Amouyel, P., Assmann, G., Bell, S., BenShlomo, Y., Berkman, L., Beulens, J.W., Björkelund, C., Blaha, M., Blazer, D.G., Bolton, T., Beaglehole, R.B., Brenner, H., Brunner, E.J., Casiglia, E., Chamnan, P., Choi, Y-H., Chowdry, R., Coady, S., Crespo, C.J., Cushman, M., Dagenais, G.R., D’Agostino Sr., R.B., Daimon, M., Davidson, K.W., Engström, G., Ford, I., Gallacher, J., Gansevoort, R.T., Gaziano, T.A., Giampaoli, S., Grandits, G., Grimsgaard, S., Grobbee, D.E., Gudnason, V., Guo, Q., Tolonen, H., Humphries, S., Iso, H., Jukema, J.W., Kauhanen, J., Kengne, A.P., Khalili, D., Koenig, W., Kromhout, D., Krumholz, H., Lam, T.H., Laughlin, G., Ibañez, A.M., Meade, T.W., Moons, K.G.M., Nietert, P.J., Ninomiya, T., Nordestgaard, B.G., O’Donnell, C., Palmieri, L., Patel, A., Perel, P., Price, J.F., Providencia, R., Ridker, P.M., Rodriguez, B., Rosengren, A., Roussel, R., Sakurai, M., Salomaa, V., Sato, S., Schöttker, B., Shara, N., Shaw, J.E.,
Shin, H-C., Simons, L.A., Sofianopoulou, E., Sundström, J., Völzke, H., Wallace, R.B., Wareham, N.J., Willeit, P., Wood, D., Wood, A., Zhao, D., Woodward, M., Danaei, G., Roth, G., Mendis, S., Onuma, O., Varghese, C., Ezzati, M., Graham, I., Jackson, R., Danesh, J., Angelantonio, E.D. 2019. World Health Organization cardiovascular disease risk charts: Revised models to estimate risk in 21 global regions. The Lancet Global Health 7(10): e1332-e1345.

Kawai, T., Takahashi, T., Esaki, M., Ushikoshi, H., Nagano, S., Fujiwara, H. \& Kosai, K.I. 2004. Efficient cardiomyogenic differentiation of embryonic stem cell by fibroblast growth factor 2 and bone morphogenetic protein 2. Circulation Journal 68(7): 691-702.

Kelecsényi, Z., Spencer, D.L. \& Caspary, W.J. 2000. Molecular analysis of 5-azacytidine-induced variants in mammalian cells. Mutagenesis 15(1): 25-31.

Knot, H.J., Laher, I., Sobie, E.A., Guatimosim, S., GomezViquez, L., Hartmann, H., Song, L.S., Lederer, W.J., Graier, W.F., Malli, R., Frieden, M. \& Petersen, O.H. 2005. Twenty years of calcium imaging: Cell physiology to dye for Molecular Interventions 5(2): 112-127.

Kuhn, N.Z. \& Tuan, R.S. 2010. Regulation of stemness and stem cell niche of mesenchymal stem cells: Implications in tumorigenesis and metastasis. Journal of Cellular Physiology 222(2): 268-277.

Leon, B.M. 2015. Diabetes and cardiovascular disease: Epidemiology, biological mechanisms, treatment recommendations and future research. World Journal of Diabetes 6(13): 1246-1258.

Li, K., Li, S.Z., Zhang, Y.L. \& Wang, X.Z. 2011. The effects of dan-shen root on cardiomyogenic differentiation of human placenta-derived mesenchymal stem cells. Biochemical and Biophysical Research Communications 415(1): 147 151 .

Li, W., Wu, D., Niu, Z., Jiang, D., Ma, H., He, H., Zuo, X., Xie, X. \& He, Y. 2016. 5-azacytidine suppresses EC9706 cell proliferation and metastasis by upregulating the expression of SOX17 and CDH1. International Journal of Molecular Medicine 38(4): 1047-1054.

Loughrey, C.M., MacEachern, K.E., Neary, P. \& Smith, G.L. 2002. The relationship between intracellular $[\mathrm{Ca}(2+)]$ and $\mathrm{Ca}(2+)$ wave characteristics in permeabilised cardiomyocytes from the rabbit. The Journal of Physiology 543(3): 859-870.

Ludman, P.F. 2018. Percutaneous coronary intervention. Medicine (United Kingdom) 46(9): 547-554.

MacLennan, D.H. \& Kranias, E.G. 2003. Phospholamban: A crucial regulator of cardiac contractility. Nature Reviews Molecular Cell Biology 4: 566-577.

Marques, S.R., Lee, Y., Poss, K.D. \& Yelon, D. 2008. Reiterative roles for FGF signaling in the establishment of size and proportion of the zebrafish heart. Developmental Biology 321(2): 397-406.

Ogawa, R., Akita, S., Akaishi, S., Aramaki-Hattori, N., Dohi, T., Hayashi, T., Kishi, K., Kono, T., Matsumura, H., Muneuchi, 
G., Murao, N., Nagao, M., Okabe, K., Shimizu, F., Tosa, M., Tosa, Y., Yamawaki, S., Ansai, S., Inazu, N., Kamo, T., Kazki, R. \& Kuribayashi, S. 2019. Diagnosis and treatment of keloids and hypertrophic scars - Japan scar workshop consensus document 2018. Burns and Trauma 7: 39.

Olesen, C., Picard, M., Winther, A.M.L., Gyrup, C., Preben Morth, J., Oxvig, C., Vuust Møller, J. \& Nissen, P. 2007. The structural basis of calcium transport by the calcium pump. Nature 450: 1036-1042.

Peter, A.K., Bjerke, M.A. \& Leinwand, L.A. 2016. Biology of the cardiac myocyte in heart disease. Molecular Biology of the Cell 27(14): 2149-2160.

Pittenger, M.F. \& Martin, B.J. 2004. Mesenchymal stem cells and their potential as cardiac therapeutics. Circulation Research 95(1): 9-20.

Segers, V.F.M. \& Lee, R.T. 2008. Stem-cell therapy for cardiac disease. Nature 451: 937-942.

Shipunova, N.N., Petinati, N.A. \& Drize, N.I. 2013. Effect of hydrocortisone on multipotent human mesenchymal stromal cells. Bulletin of Experimental Biology and Medicine 155(1): 159-163.

Steinhauser, M.L. \& Lee, R.T. 2011. Regeneration of the heart. EMBO Molecular Medicine 3(12): 701-712.

Stern-Straeter, J., Bonaterra, G.A., Juritz, S., Birk, R., Goessler, U.R., Bieback, K., Bugert, P., Schultz, J., Hörmann, K., Kinscherf, R. \& Faber, A. 2014. Evaluation of the effects of different culture media on the myogenic differentiation potential of adipose tissue- or bone marrow-derived human mesenchymal stem cells. International Journal of Molecular Medicine 33(1): 160-170.

Yin, Z., Ren, J. \& Guo, W. 2015. Sarcomeric protein isoform transitions in cardiac muscle: A journey to heart failure. Biochimica et Biophysica Acta - Molecular Basis of Disease 1852(1): 47-52.
Yoon, Y.S., Park, J.S., Tkebuchava, T., Luedeman, C. \& Losordo, D.W. 2004. Unexpected severe calcification after transplantation of bone marrow cells in acute myocardial infarction. Circulation 109(25): 3154-3157.

Zhang, Y., Mignone, J. \& Robb Maclellan, W. 2015. Cardiac regeneration and stem cells. Physiological Reviews 95(4): 1189-1204

Zhao, Y., Li, T., Wei, X., Bianchi, G., Hu, J., Sanchez, P.G., Xu, K., Zhang, P., Pittenger, M.F., Wu, Z.J. \& Griffith, B.P. 2012. Mesenchymal stem cell transplantation improves regional cardiac remodeling following ovine infarction. STEM CELLS Translational Medicine 1(9): 685-695.

Nadiah Sulaiman*, Nur Qisya Afifah Veronica Sainik, Shamsul Bin Sulaiman, Pezhman Hafez, Ng Min Hwei \& Ruszymah Bt Hj Idrus

Tissue Engineering Centre

Faculty of Medicine

Universiti Kebangsaan Malaysia

Jalan Yaacob Latiff, Bandar Tun Razak

56000 Cheras, Kuala Lumpur, Federal Territory

Malaysia

Nur Qisya Afifah Veronica Sainik \& Ruszymah Bt Hj Idrus Department of Physiology

Faculty of Medicine

Universiti Kebangsaan Malaysia

Jalan Yaacob Latiff, Bandar Tun Razak

56000 Cheras, Kuala Lumpur, Federal Territory

Malaysia

*Corresponding author; email: nadiahsulaiman@ukm.edu.my

Received: 27 April 2020

Accepted: 13 November 2020 